\title{
Pemodelan Spasial Skenario Pengembangan Lahan Perkebunan Kelapa Sawit di Provinsi Kalimantan Tengah
}

\author{
Stanley Adrian dan Putu Gde Ariastita \\ Departemen Perencanaan Wilayah dan Kota, Fakultas Arsitektur, Desain dan Perencanaan, \\ Institut Teknologi Sepuluh Nopember (ITS) \\ e-mail: ariastita@urplan.its.ac.id
}

\begin{abstract}
Abstrak-Pengembangan lahan perkebunan kelapa sawit cenderung berkembang tanpa arah sehingga berdampak terhadap kerusakan lingkungan dan deforestasi hutan, disatu sisi lahan perkebunan kelapa sawit memberikan keuntungan yang besar terhadap perekonomian daerah di Provinsi Kalimantan Tengah. Untuk itu, pengembangan lahan perkebunan kelapa sawit perlu diatur melalui upaya perumusan model spasial berdasarkan skenario pengembangan lahan perkebunan kelapa sawit agar nilai lingkungan dapat terus terjaga. Tujuan dari penelitian ini adalah untuk merumuskan model spasial berdasarkan skenario pengembangan lahan perkebunan kelapa sawit di Provinsi Kalimantan Tengah. Penelitian ini menggunakan analisis Cellular Automata untuk melakukan pemodelan spasial yang terdiri atas beberapa skenario. Dari hasil penelitian dengan menggunakan Cellular Automata, diperoleh 3 model simulasi yaitu (1) Model simulasi berdasarkan trend, (2) Model simulasi berdasarkan target pedoman teknis, dan (3) Model simulasi berdasarkan target RTRW. Model simulasi berdasarkan trend menunjukkan pengembangan lahan perkebunan kelapa sawit pada hutan produksi sebesar 950.950 Ha, sedangkan model simulasi berdasarkan target pedoman teknis sebesar 755.206,25 Ha dan model simulasi berdasarkan target RTRW sebesar 769.393,75 Ha. Dari ketiga model simulasi, pengembangan lahan perkebunan kelapa sawit di Provinsi Kalimantan Tengah lebih sesuai diterapkan pada model simulasi berdasarkan target RTRW karena pengembangan lahan perkebunan kelapa sawit pada hutan produksi hanya dilakukan pada jenis lahan hutan produksi yang dapat dikonversi.
\end{abstract}

Kata Kunci-Lahan Perkebunan Kelapa Sawit, Cellular Automata, Alih Fungsi Lahan Hutan Produksi.

\section{PENDAHULUAN}

$\mathrm{P}$ ERENCANAAN tata guna lahan memiliki pengertian sebagai proses perencanaan terhadap penggunaan atau pemanfaatan lahan dan alternatif pola tata guna lahan dengan mempertimbangkan faktor pengembangannya, baik fisik, sosial, budaya, maupun ekonomi [1]. Sehingga tujuan dari perencanaan tata guna lahan adalah menghasilkan suatu sasaran tertentu yang berperan dalam melakukan penentuan pilihan dan penerapan salah satu pola tata guna lahan yang terbaik dan sesuai dengan kondisi yang ada.

Provinsi Kalimantan Tengah merupakan salah satu wilayah dengan pola tata guna lahan yang beragam. Salah satu jenis penggunaan lahan yang saat ini sedang berkembang adalah lahan perkebunan kelapa sawit. Pada tahun 2017, luasan perkebunan kelapa sawit telah mencapai 1.495.468,40 Ha atau kenaikan mencapai $22 \%$ apabila dibandingkan dengan 5 tahun sebelumnya [2]. Luasan lahan tersebut telah berkontribusi memberikan keuntungan $25 \%$ dari PDRB provinsi dan mendominasi sektor pertanian [3]. Artinya kelapa sawit telah menjadi faktor pendorong terpenting untuk pertumbuhan ekonomi dan pembangunan sosial ekonomi di Provinsi Kalimantan Tengah.

Namun, selain memberikan nilai ekonomis yang tinggi, kelapa sawit juga menyebabkan deforestasi dan kerusakan lingkungan. Kerusakan yang ditimbulkan meliputi pencemaran air, sendimentasi, penggunaan pestisida yang berlebihan, dan berkurangnya kesuburan tanah [3] Berdasarkan data Dinas Perkebunan Provinsi Kalimantan Tengah tahun 2007, sekitar 816 ribu hektar kawasan hutan di Kalimantan Tengah telah dilepaskan untuk perkebunan kelapa sawit [4]. Hal ini menunjukan bahwa pengembangan areal perkebunan kelapa sawit cenderung dilakukan tanpa memperhatikan aspek lingkungan dan lebih mendahulukan nilai ekonomi.

Berdasarkan hal tersebut, adanya potensi pengembangan lahan perkebunan kelapa sawit pada Provinsi Kalimantan Tengah ternyata telah diiringi dengan timbulnya indikasiindikasi ketidaksesuaian pengembangan lahan perkebunan kelapa sawit terhadap rencana tata ruang yang ada. Apabila kondisi demikian terus dibiarkan, maka terwujudnya kesesuaian pemanfaatan guna lahan perkebunan kelapa sawit akan menjadi sulit terwujud. Agar permasalahan yang timbul pada kawasan penelitian tidak semakin membesar, maka perlu dirumuskan model spasial berdasarkan skenario pengembangan lahan perkebunan kelapa sawit di Provinsi Kalimantan Tengah. Perumusan model spasial perlu dilakukan berdasarkan beberapa pendekatan yang secara logis dan teknis dapat diterima dan diaplikasikan sehingga dapat menjawab permasalahan pengembangan lahan yang mungkin terjadi pada masa yang akan datang. 


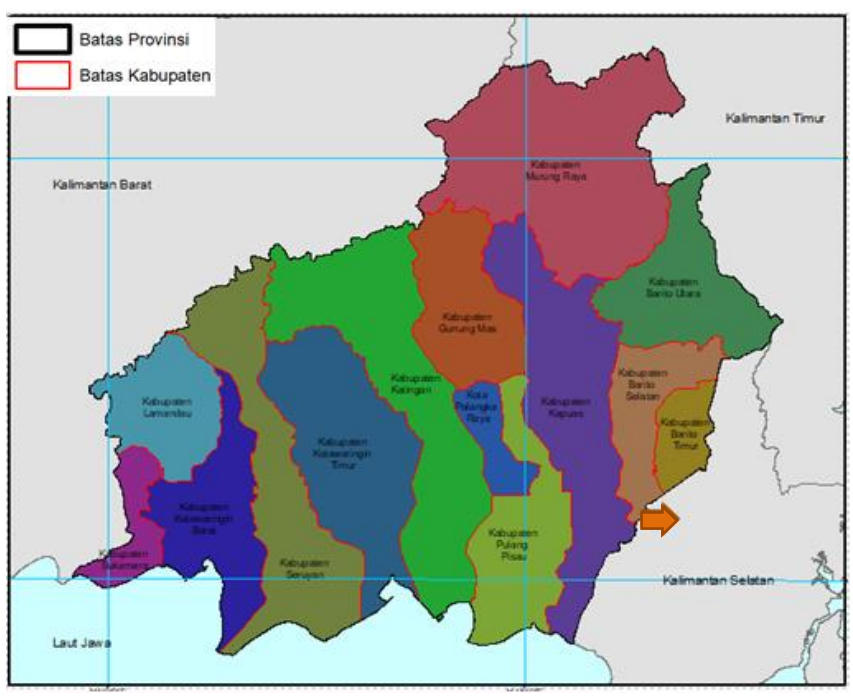

Gambar 1. Peta wilayah penelitian.

\section{METODOLOGI PENELITIAN}

\section{A. Metode pengumpulan data}

Metode pengumpulan data yang digunakan dalam penelitian ini adalah metode survei primer dan survei sekunder. Survei primer dilakukan dengan wawancara guna mengeksplor lebih dalam mengenai teori-teori yang telah didapatkan pada tinjauan pustaka kepada responden. Wawancara dilakukan untuk menentukan variabel-variabel apa saja yang berpengaruh terhadap perkembangan lahan perkebunan kelapa sawit beserta besar bobot pada masingmasing variabel tersebut. Sementara itu, survei sekunder dilakukan melalui survei instansional untuk mengetahui gambaran umum wilayah dan data perkebunan kelapa sawit di wilayah penelitian. Peta wilayah penelitian sebagaimana ditunjukkan pada Gambar 1.

\section{B. Metode Analisis}

Untuk merumuskan model spasial berdasarkan skenario pengembangan lahan perkebunan kelapa sawit di Provinsi Kalimantan Tengah dilakukan beberapa tahapan analisis berikut:

\section{Identifikasi faktor-faktor yang mempengaruhi perkembangan lahan perkebunan kelapa sawit}

Identifikasi variabel penelitian didapatkan dari kajian teori kemudian disimpulkan berdasarkan pemahaman dari peneliti dan disesuaikan dengan kondisi yang terdapat di lokasi penelitian. Setelah variabel-variabel ditentukan, selanjutnya adalah mengkonfirmasi variabel-variabel tersebut kepada stakeholder terpilih sekaligus diberikan nilai bobot pengaruhnya terhadap penentuan kawasan perkebunan kelapa sawit. Analisis perhitungan variabelvariabel tersebut menggunakan Analytical Hierarchy Process (AHP). AHP merupakan teknik analisis yang mengorganisasikan suatu informasi untuk menentukan alternatif pilihan yang paling disukai (prioritas) berdasarkan persepsi rasional seseorang (pakar). Hirarki didefinisikan sebagai suatu representasi dari sebuah permasalahan yang kompleks dalam suatu struktur multi level dimana level pertama adalah tujuan, yang diikuti level faktor, kriteria, sub kriteria, dan seterusnya ke bawah hingga level terakhir dari alternatif [5]. Pada penelitian ini, AHP akan digunakan untuk mengetahui bobot dari masing-masing alternatif yang di wakili oleh indikator dan variabel penelitian. Nilai bobot dikumpulkan dari pendapat berbagai pakar yang memiliki keterlibatan dalam penelitian ini. Proses pembobotan akan menggunakan software otomatis dengan expert choice/. Bobot yang didapatkan akan digunakan sebagai input yang akan menjadi peta transisi untuk simulasi skenario perkembangan lahan perkebunan kelapa sawit di Provinsi Kalimantan Tengah.

2. Merumuskan model spasial berdasarkan skenario pengembangan lahan perkebunan kelapa sawit.

Perumusan model spasial berdasarkan skenario pengembangan lahan perkebunan kelapa sawit dilakukan dengan menggunakan analisis cellular automata. Cellular automata merupakan metode terbaik saat ini dalam melakukan simulasi spasial (bottom-up dan top-down), termasuk simulasi landuse. Cellular automata hanya dapat dilakukan dengan mekanisme komputasi [6]. Proses simulasi akan menggunakan software Landusesim. LanduseSim merupakan software yang memiliki yang memiliki kemampuan untuk mensimulasikan multi-landuse hingga maksimal 20 unit landuse yang tumbuh secara bersamaan. LanduseSim merupakan stand-alone software dimana bukan merupakan extension sebuah software sehingga dalam operasionalnya memerlukan software lainnya seperti ArcGis guna mengolah data awal yang diperlukan sebagai input pada LanduseSim [6] (Gambar 2).

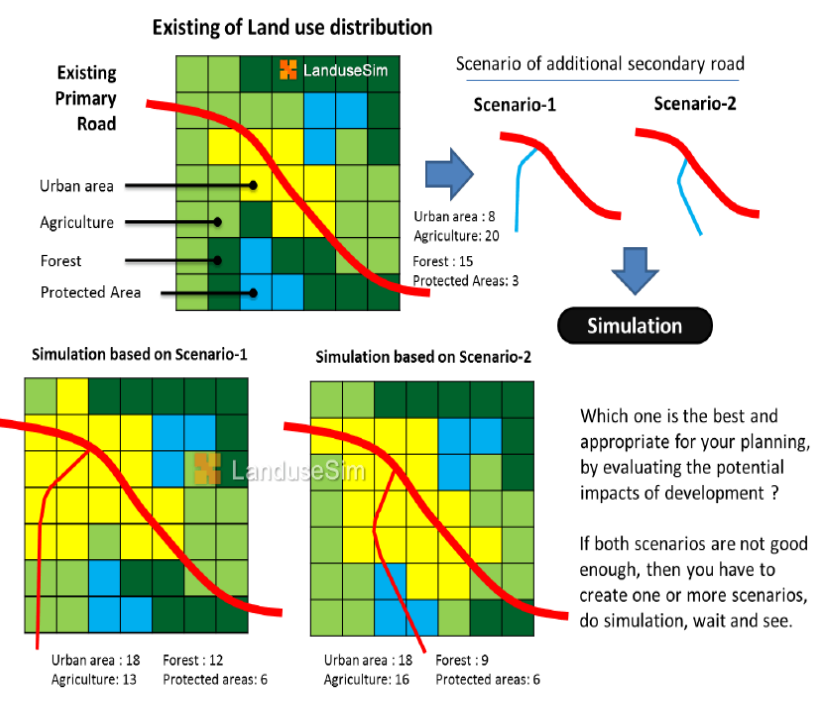

Gambar 2. Proses Simulasi Landusesim [6].

Dalam melakukan analisis cellular automata, perlu dilakukan beberapa tahapan sebagai berikut:

1. Mempersiapkan peta penggunaan lahan Provinsi Kalimantan Tengah tahun 2017 dan peta driven factors atau faktor yang mempengaruhi perkembangan lahan perkebunan kelapa sawit.

2. Analisis prediksi kebutuhan luas lahan perkebunan kelapa sawit. Perhitungan dilakukan dengan mengetahui jumlah luas kebutuhan perkebunan kelapa sawit pada tahun 2037 berdasarkan data perkembangan lahan perkebunan kelapa sawit dari tahun 2009-2017.

3. Mempersiapkan peta batasan pengembangan (perlu dipersiapkan, nilai batasan adalah nol dan nilai bukan batasan adalah satu), maka dapat dilakukan penggabungan sehingga wilayah potensi pertumbuhan landuse tidak dapat berubah pada area yang memiliki batasan. 
4. Analisis perhitungan ketetanggaan (Neighborhood Filter) pada sistem grid dimana analisis ini bertujuan untuk memberikan ruang bagi perkembangan cell lahan perkebunan kelapa sawit dengan memberikan efek suatu nilai (center) terhadap cell tetangganya kaitannya dengan pengembangan perkebunan kelapa sawit. Sel-sel tetangga (neighborhoods) merupakan bagian penting yang merepresentasikan kesatuan cell yang berinteraksi langsung dengan pusat cell.

5. Menentukan aturan transisi sebagai bentuk manipulasi yang dilakukan dalam Landusesim untuk memastikan ketepatan laju konversi. Dalam aturan transisi ditentukan lahan aktif tidak boleh mengkonversi lahan lainnya. Sehingga didapatkan model yang sesuai dengan realitas fenomena di lapangan.

Output dari kelima tahapan diatas selanjutnya akan menjadi input dalam analisis cellular automata yang dilakukan dengan bantuan software LanduseSim 2.3.1 dan dihasilkan output peta model spasial skenario pengembangan lahan perkebunan kelapa sawit di Provinsi Kalimantan Tengah selama 20 tahun mendatang, yaitu pada tahun 2037.

\section{HASIL DAN PEMBAHASAN}

\section{A. Identifikasi faktor-faktor yang mempengaruhi} perkembangan lahan perkebunan kelapa sawit

Input yang dijadikan sebagai masukan dalam analisis ini adalah variabel-variabel awal yang dianggap berpengaruh dalam menentukan perkembangan lahan perkebunan kelapa sawit di Provinsi Kalimantan Tengah. Variabelvariabel tersebut didapatkan berdasarkan hasil kajian pustaka yang telah dilakukan pada pembahasan sebelumnya. Adapun variabel-variabel awal yang didapatkan tersebut terbagi kedalam 3 faktor sebagai berikut:

1. Faktor Iklim, dengan variabel curah hujan dan suhu.

2. Faktor Lahan, dengan variabel kelerengan, jenis tanah rawan erosi dan rawan banjir.

3. Faktor Lokasi, dengan variabel jarak dari pusat perkotaan, jarak dari lahan pertambangan, jarak dari sungai dan jarak dari kegiatan industri pengolahan kelapa sawit.

Adapun responden yang digunakan dalam proses AHP ini sebanyak 6 orang responden yang didapatkan berdasarkan kriteria dengan teknik purposive sampling. Hasil akhir dari proses AHP adalah pembobotan pada setiap faktor dan variabel yang mempengaruhi perkembangan lahan perkebunan kelapa sawit di Provinsi Kalimantan Tengah. Tabel 1 merupakan hasil dari pembobotan dari setiap responden.

Tabel 1.

Besar Bobot Faktor dalam Mempengaruhi Perkembangan Lahan Perkebunan Kelapa Sawit

\begin{tabular}{|c|c|}
\hline Faktor & Besar Bobot \\
\hline Curah hujan & 0,045 \\
\hline Suhu & 0,009 \\
\hline Kelerengan & 0,028 \\
\hline Jenis tanah & 0,065 \\
\hline Rawan erosi & 0,160 \\
\hline Rawan banjir & 0,276 \\
\hline Jarak dari pusat perkotaan & 0,031 \\
\hline Kedekatan dengan sungai & 0,100 \\
\hline Jarak dari lokasi pertambangan & 0,047 \\
\hline
\end{tabular}

\begin{tabular}{cc}
\hline Kedekatan dengan industri pengolahan & 0,239 \\
Total & 1,000 \\
\hline \hline
\end{tabular}

Berdasarkan hasil analisis AHP untuk total semua variabel antar faktor yang mempengaruhi perkembangan lahan perkebunan kelapa sawit di Provinsi Kalimantan Tengah, variabel yang memiliki pengaruh paling besar adalah variabel bahaya banjir dengan bobot $(0,276)$. Di urutan kedua adalah variabel jarak dari lokasi industri pengolahan kelapa sawit dengan bobot $(0,239)$. Variabel bahaya erosi dan kedekatan dengan sungai berada pada urutan ke tiga dan empat. Bobot terendah merupakan variabel suhu dengan bobot $(0,009)$ Adapun nilai inconsistency pada perbandingan variabel antar semua faktor sebesar 0,03 yang berarti bahwa tingkat kesalahan dalam analisis ini adalah $3 \%$. Nilai bobot setiap variabel pada analisis ini selanjutnya akan digunakan sebagai input untuk analisis cellular automata dengan software Landusesim seperti yang penelitian yang telah dilakukan oleh Pratomoatmojo [7].

\section{B. Merumuskan model spasial berdasarkan skenario pengembangan lahan perkebunan kelapa sawit.}

Pada analisis ini model spasial dibagi menjadi 3 skenario, yaitu skenario berdasarkan trend, target pedoman teknis dan target RTRW.

1. Model spasial berdasarkan skenario trend

Merupakan simulasi untuk melihat gambaran kondisi masa depan pada tahun 2037 dengan asumsi bahwa lahan perkebunan kelapa sawit bertumbuh secara konstan.

a. Prediksi Kebutuhan Luas Lahan Perkebunan Kelapa

Sawit di Provinsi Kalimantan Tengah

Prediksi kebutuhan luas lahan perkebunan kelapa sawit didapatkan dengan melihat pola perkembangan penggunaan lahan perkebunan kelapa sawit kemudian dilakukan identifikasi perkembangan penggunaan lahan tersebut setiap tahun dengan dibagi 9 yaitu periode 2009 2017. Langkah selanjutnya adalah perkembangan rata-rata setiap tahun penggunaan lahan tersebut dikalikan dengan 20 yaitu tahun tujuan prediksi. Adapun rentang waktu yang ditentukan dalam memprediksi kebutuhan luas lahan perkebunan kelapa sawit di Provinsi Kalimantan Tengah adalah selama 20 tahun kedepan yaitu prediksi untuk simulasi tahun 2037. Hal ini dikarenakan mengikuti pertimbangan kegiatan perencanaan wilayah pada umumnya selalu menggunakan rentang waktu selama 20 tahun (sebagai contoh dokumen RTRW dan RDTRK). Berdasarkan metode perhitungan tersebut, diketahui bahwa pada tahun 2037 estimasi luas perkebunan kelapa sawit sebesar 2.959.880,40 Ha atau bertambah sebesar 1.464.412 Ha dari luasan saat ini.

b. Membuat daerah jangkauan pengaruh masing-masing faktor-faktor dengan menggunakan tools Euclidean Distance.

Tahapan ini bertujuan untuk mengetahui jarak jangkauan masing-masing faktor terhadap penggunaan lahan yang akan disimulasikan perkembangannya. Masing-masing faktor memiliki kriteria tersendiri dalam mempengaruhi perkembangan lahan perkebunan kelapa sawit. Melalui proses ini, maka diketahui jarak maksimum dan besar jarak minimum masing-masing faktor dalam mempengaruhi perkembangan penggunaan lahan. Setiap jarak dari faktorfaktor tersebut memiliki arti pengaruhnya masing-masing. 
Selanjutnya, data jarak masing-masing faktor tersebut dikonversikan kedalam format ASCII melalui tools Raster to ASCII. Format ASCII memungkinkan data hasil analisis pada software ArcGis untuk dibaca pada software LanduseSim.

c. Penyusunan Peta Transisi/ Suitability of Landuse

Peta Transisi adalah peta yang menunjukan probabilitas suatu lokasi untuk berubah menjadi penggunaan lahan tertentu. Peta transisi ini berguna untuk menunjukan arah perkembangan suatu penggunan lahan. Peta transisi akan digunakan untuk mengetahui kecocokan suatu lokasi terhadap penggunaan lahan tertentu. Untuk menyusun peta transisi berikut langkah-langkah yang digunakan.

1. Mengkonversi data jarak (Eucledian Distance) masingmasing faktor menjadi nilai fuzzy.

Tahap ini bertujuan untuk menentukan arah pengaruh masing-masing faktor terhadap perkembangan lahan perkebunan kelapa sawit. Nilai fuzzy terdiri atas dua kategori, yaitu Monotonically Increasing untuk faktor yang apabila semakin jauh jaraknya maka semakin besar potensi perkembangan lahan perkebunan kelapa sawit pada daerah tersebut, dan Monotically Decreasing untuk faktor apabila semakin dekat maka semakin besar potensi perkembangan lahan perkebunan kelapa sawit pada daerah tersebut. Faktor yang memiliki nilai monotically increasing adalah faktor curah hujan, suhu, kelerengan, jenis tanah, rawan erosi, rawan banjir, jarak dari pusat perkotaan dan jarak dari lokasi pertambangan. Sedangkan faktor yang memiliki nilai monotically decreasing adalah faktor kedekatan dengan sungai dan kedekatan dengan lokasi industri pengolahan.

2. Membuat peta potensi arah perkembangan lahan perkebunan kelapa sawit.

Tahap ini dilakukan dengan melakukan overlay terhadap peta-peta hasil fuzzy pada langkah sebelumnya. Adapun overlay dilakukan dengan memasukkan nilai bobot masingmasing faktor yang telah dikonversi nilainya pada rentang $0-1$. Semakin besar nilai bobot yang dimiliki oleh sebuah faktor, maka semakin besar pula faktor tersebut mempengaruhi perkembangan lahan perkebunan kelapa sawit suatu kawasan.

\section{d. Penyusunan Peta Batasan Pengembangan}

Peta batasan pengembangan adalah peta yang memiliki batasan sehingga penggunaan lahan yang di simulasikan tidak dapat berkembang pada wilayah yang menjadi batasan. Kawasan yang menjadi batasan wilayah pengembangan lahan perkebunan kelapa sawit adalah wilayah yang berpotensi terjadi bencana banjir dan bencana erosi yang cukup tinggi. Dalam hal ini, pengembangan lahan perkebunan kelapa sawit tidak akan berkembang pada kawasan yang memiliki potensi terjadinya bencana banjir dan erosi yang cukup tinggi.

e. Membentuk Neighborhood Filter

Neighborhood filter yang akan digunakan pada simulasi adalah 3x3 dengan fungsi simulasi Sum. Artinya, simulasi akan dilakukan dengan mencari nilai total pada perkalian antara bobot NF, nilai suitability $N F$, dan $N F$ conversion probability. Pada masing-masing inti cell hanya akan memberikan pengaruh pada satu cell tetangga disekitarnya. f. Menentukan Transition Rules

Transition Rules yang terdiri atas beberapa ketentuan yakni sebagai berikut:
Cell Growth, yakni menunjukkan besar pertumbuhan cell lahan perkebunan kelapa sawit yang akan disimulasikan. Berdasarkan analisis prediksi kebutuhan luas lahan perkebunan kelapa sawit pada kawasan penelitian, dibutuhkan penambahan luas lahan sebesar 1.464.412 Ha. Sehingga, apabila dikonversikan nilai cell yang digunakan adalah $250 \mathrm{~m}$ x $250 \mathrm{~m}$, maka diperkirakan perkembangan lahan perkebunan kelapa sawit mengalami penambahan jumlah cell sebesar 234.305,92 cell.

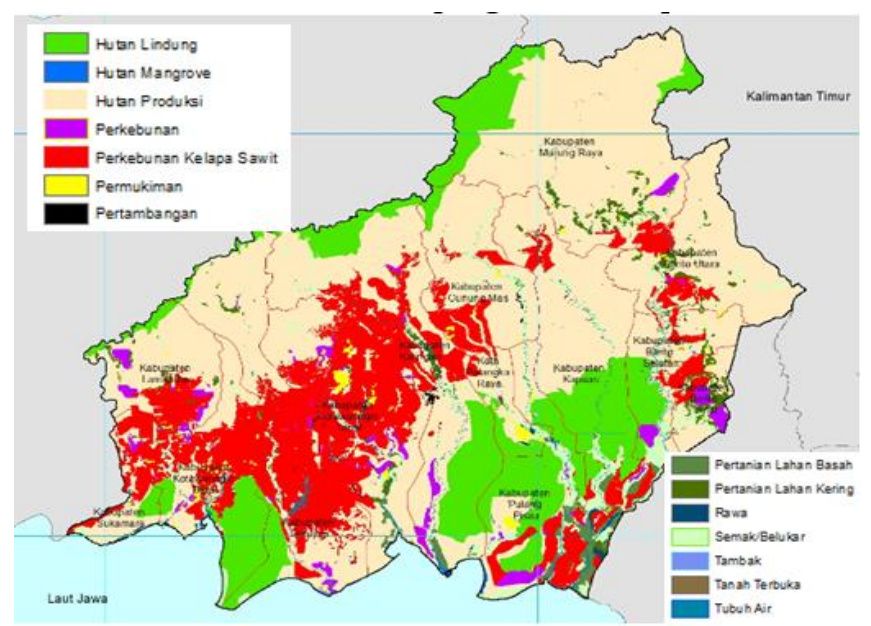

Gambar 2. Peta model spasial berdasarkan trend.

Constraint Landuse, yakni menunjukkan landuse yang memiliki batasan pengembangan, sehingga landuse tersebut tidak akan berubah dan tetap terkait dengan berkembangnya lahan perkebunan kelapa sawit yang disimulasikan. Penggunaan lahan yang termasuk dalam constraint landuse adalah hutan lindung, hutan mangrove, permukiman, pertambangan, tambak dan tubuh air (sungai). Penentuan constraint landuse berdasarkan matriks perubahan penggunaan lahan 2009-2017 dimana lahan perkebunan kelapa sawit hanya mengkonversi hutan produksi, perkebunan lainnya, pertanian lahan basah, pertanian lahan kering, rawa, semak/belukar dan tanah terbuka. Sedangkan lahan yang tidak di konversi oleh lahan perkebunan kelapa sawit akan dijadikan sebagai constraint landuse.

g. Hasil Model Spasial Berdasarkan Trend

Arah perkembangan lahan perkebunan kelapa sawit terkonsentasi pada wilayah yang aman dari bencana banjir dan mendekati lokasi industri pengolahan kelapa sawit.

2. Model spasial berdasarkan skenario target pedoman teknis

Model spasial pada penelitian ini bertujuan untuk mengetahui pola pengembangan lahan perkebunan kelapa sawit pada tahun 2037 berdasarkan kemungkinankemungkinan yang dapat terjadi malalui tinjauan pedoman teknis. Berikut merupakan acuan-acuan yang digunakan dalam analisis skenario perkembangan lahan perkebunan kelapa sawit di Provinsi Kalimantan Tengah.

Tabel 2.

Ketentuan Tinjauan Pedoman Teknis

\begin{tabular}{lrrlrr}
\hline \hline \multicolumn{3}{c}{ Pedoman } & \multicolumn{3}{c}{ Keterangan } \\
\hline Peraturan & Daerah & Prov. & Kebijakan dan program pada RPJP \\
Kalimantan & Tengah No. 4 Th. & Provinsi Kalimantan & Tengah \\
$2010 \quad$ tentang & Rencana & menjelaskan tentang adanya \\
Pembangunan Jangka & Panjang & peningkatan luasan kebun kelapa sawit \\
Daerah Prov. Kalimantan Tengah & pada tahun & 2005-2025 di Provinsi
\end{tabular}




\begin{tabular}{|c|c|}
\hline Th. 2005-2025 & Kalimantan Tengah \\
\hline $\begin{array}{l}\text { Peraturan Daerah Prov. } \\
\text { Kalimantan Tengah No. } 1 \text { Th } 2017 \\
\text { tentang Rencana Pembangunan } \\
\text { Jangka Menengah Daerah Prov. } \\
\text { Kalimantan Tengah Th. 2016- } \\
2021\end{array}$ & $\begin{array}{l}\text { Kebijakan dan program pada RPJMD } \\
\text { Kalimantan Tengah menjelaskan } \\
\text { tentang fokus pada peningkatan } \\
\text { produtivitas perkebunan kelapa sawit } \\
\text { tanpa adanya penambahan luasan dari } \\
\text { tahun 2016-2021 di Provinsi } \\
\text { Kalimantan Tengah }\end{array}$ \\
\hline $\begin{array}{l}\text { PERMEN Pekerjaan Umum dan } \\
\text { Perumahan Rakyat Republik } \\
\text { Indonesia No. 28/Prt/M/2015 } \\
\text { tentang Penetapan Garis Sempadan } \\
\text { Sungai dan Garis Sempadan } \\
\text { Danau }\end{array}$ & $\begin{array}{l}\text { Garis sempadan sungai besar tidak } \\
\text { bertanggul di luar kawasan perkotaan } \\
\text { paling sedikit berjarak } 100 \text { (seratus) } \\
\text { meter dari tepi kiri dan kanan palung } \\
\text { sungai sepanjang alur sungai. }\end{array}$ \\
\hline $\begin{array}{l}\text { PP Republik Indonesia No. } 57 \text { Th. } \\
2016 \text { tentang Perubahan Atas } \\
\text { Peraturan Pemerintah No. } 71 \text { Th. } \\
2014 \text { tentang Perlindungan dan } \\
\text { Pengelolaan Ekosistem Gambut }\end{array}$ & $\begin{array}{l}\text { Peraturan ini menjelaskan tentang tidak } \\
\text { diperbolehkannya ada kegiatan } \\
\text { budidaya pada areal lahan gambut }\end{array}$ \\
\hline
\end{tabular}

Berdasarkan pedoman ketentuan yang telah dibahas sebelumnya, maka perlu dilakukan peninjauan terhadap hal-hal tersebut. Kebijakan pada RPJP Provinsi Kalimantan Tengah menjelaskan tentang adanya pengembangan luas lahan perkebunan kelapa sawit dari tahun 2005-2025, namun kebijakan dan program pada RPJM Provinsi Kalimantan Tengah lebih fokus pada peningkatan produktivitas areal perkebunan tanpa adanya penambahan luasan lahan pada tahun 2016-2021. Sehingga dari kebijakan tersebut dapat ditarik kesimpulan bahwa skenario pengembangan lahan perkebunan kelapa sawit di Provinsi Kalimantan Tengah hanya akan dilakukan simulasi penambahan luas lahan perkebunan kelapa sawit pada tahun 2022-2037. Sedangkan pada tahun 2018-2021 tidak disimulasikan untuk penambahan luas lahan. Selain itu, simulasi pengembangan lahan perkebunan kelapa sawit juga di dukung dengan penambahan garis sempadan sungai berjarak 100 (seratus) meter dan lahan gambut sebagai wilayah yang dijadikan batasan pengembangan (constraint) sehingga lahan perkebunan kelapa sawit tidak akan berkembang pada areal tersebut sesuai dengan pedoman diatas.

Tahapan simulasi skenario pengembangan lahan perkebunan kelapa sawit berdasarkan target hampir sama dengan analisis sebelumnya, dimana variabel dan bobot tiap variabel yang digunakan tetap sama. Namun yang membedakan simulasi ini dengan simulasi sebelumnya adalah total penambahan kebutuhan luas lahan untuk tahun 2037 dan penambahan areal constraint pada sempadan sungai dan lahan gambut. Metode perhitungan kebutuhan luas lahan perkebunan kelapa sawit untuk tahun 2037 tetap sama dengan metode perhitungan berdasarkan simulasi sebelumnya, namun pada simulasi ini, kebutuhan luas lahan sebesar 1.171.529,6 Ha atau berkurang sebesar 292.882,40 Ha (terjadi pengurangan penambahan luas lahan perkebunan kelapa sawit dari tahun 2018-2021). Gambar 3 merupakan hasil simulasi skenario perkembangan lahan perkebunan kelapa sawit berdasarkan target pedoman teknis.

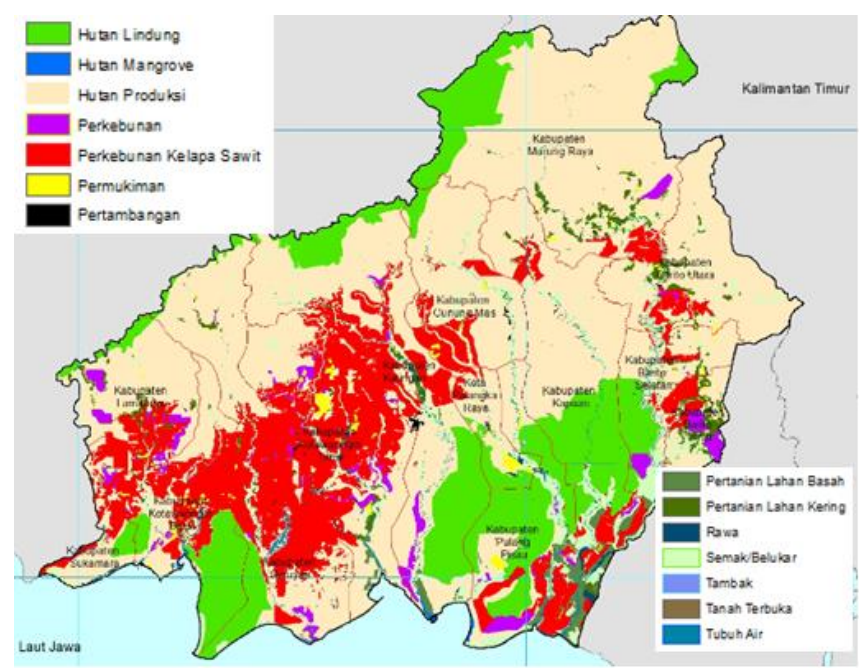

Gambar 3. peta model spasial berdasarkan pedoman teknis.

\section{Model spasial berdasarkan target RTRW}

Model spasial pada penelitian ini bertujuan untuk mengetahui pola pengembangan lahan perkebunan kelapa sawit pada tahun 2037 berdasarkan kemungkinankemungkinan yang dapat terjadi malalui tinjauan target RTRW Provinsi Kalimantan Tengah. Berdasarkan RTRW Provinsi Kalimantan Tengah 2015-2035 dijelaskan bahwa pada Provinsi Kalimantan Tengah akan dialokasikan jenis peruntukan lahan hutan produksi yang dibagi menjadi 3 yaitu hutan produksi tetap sebesar 3955815,94 Ha, hutan produksi terbatas sebesar 3181149,10 Ha dan hutan produksi yang dapat dikonversi sebesar 1983071,53 Ha. Dari alokasi ke tiga lahan hutan produksi tersebut, lahan hutan produksi tetap dan hutan produksi terbatas akan dijadikan variabel yang menjadi batasan pengembangan (constraint) sehingga pengembangan lahan perkebunan kelapa sawit yang mengkonversi lahan hutan produksi hanya akan mengkonversi jenis lahan hutan produksi yang dapat dikonversi saja.

Tahapan simulasi skenario pengembangan lahan perkebunan kelapa sawit berdasarkan target RTRW hampir sama dengan analisis sebelumnya, dimana variabel dan bobot tiap variabel yang digunakan tetap sama. Analisis kebutuhan lahan pada skenario ini menggunakan analisis perhitungan yang sama dengan kebutuhan lahan pada skenario berdasarkan trend dengan total kebutuhan luas lahan untuk tahun 2037 sebesar 1.464.755 Ha (234360,8 cell). Gambar 4 merupakan hasil simulasi skenario perkembangan lahan perkebunan kelapa sawit berdasarkan target RTRW. 


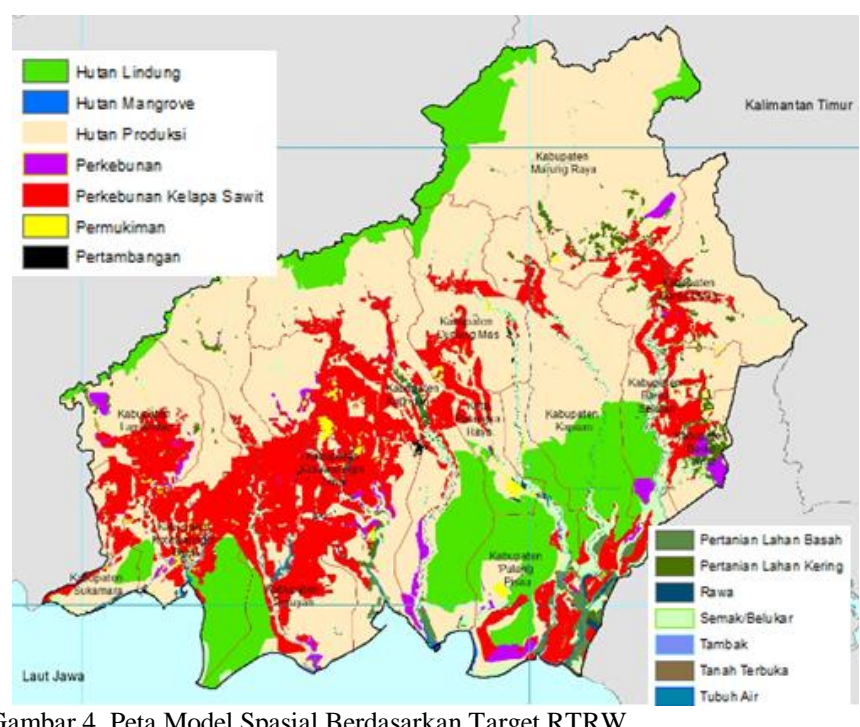

Gambar 4. Peta Model Spasial Berdasarkan Target RTRW.

\section{Komparasi Model Spasial Skenario Pengembangan Lahan Perkebunan Kelapa Sawit}

Analisis ini bertujuan untuk mengetahui perbedaan luas pengembangan lahan perkebunan kelapa sawit pada masing-masing skenario yang telah terbentuk. Analisis ini dilakukan dengan mengkomparasi besar luasan lahan pada masing-masing hasil skenario (Gambar 5):

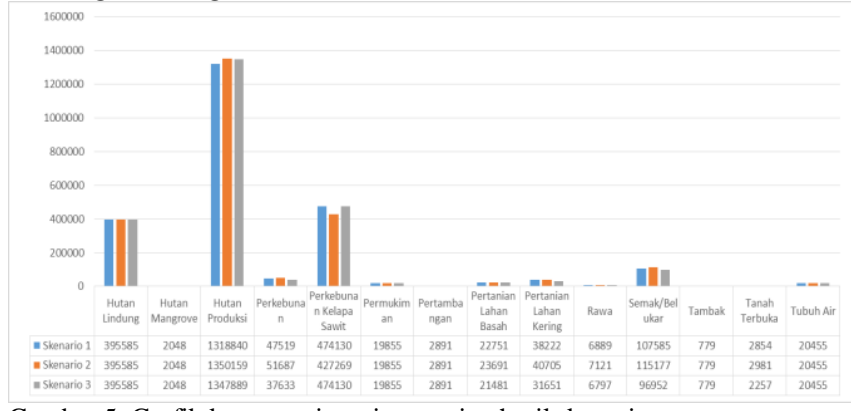

Gambar 5. Grafik komparasi masing-masing hasil skenario.

Berdasarkan grafik komparasi di atas, diketahui bahwa lahan perkebunan kelapa sawit mengalami peningkatan yang cukup tinggi yaitu pada model spasial berdasarkan skenario trend dan target RTRW mengalami kenaikan mencapai $97,70 \%$ sedangkan model spasial berdasarkan pedoman teknis mengalami kenaikan sebesar 78,16\%. Model simulasi berdasarkan trend menunjukkan pengembangan lahan perkebunan kelapa sawit pada hutan produksi paling besar yaitu $950.950 \mathrm{Ha}$, sedangkan model simulasi berdasarkan target pedoman teknis sebesar 755.206,25 Ha dan model simulasi berdasarkan target RTRW sebesar 769.393,75 Ha.

Mengacu pada urgensi penelitian, dimana hasil akhir yang diharapkan dari penelitian ini adalah terbentuknya suatu model spasial yang dapat mengatasi permasalahan terkait pengembangan lahan perkebunan kelapa sawit yang sering mengkonversi lahan hutan di Provinsi Kalimantan Tengah. Dari ketiga model spasial, pengembangan lahan perkebunan kelapa sawit di Provinsi Kalimantan Tengah lebih sesuai diterapkan pada model spasial berdasarkan target RTRW karena pengembangan lahan perkebunan kelapa sawit pada hutan produksi hanya dilakukan pada jenis lahan hutan produksi yang dapat dikonversi, sedangkan model simulasi berdasarkan skenario trend dan pedoman teknis tidak di akomodasi oleh pembagian jenis hutan produksi sehingga pengembangan lahan perkebunan kelapa sawit juga mengkonversi lahan hutan produksi tetap dan hutan produksi terbatas.

\section{KESIMPULAN}

Berdasarkan hasil analisa dan pembahasan yang telah dilakukan pada penelitian ini, maka dapat disimpulkan bahwa:

1. Variabel-variabel yang mempengaruhi perkembangan lahan perkebunan kelapa sawit di Provinsi Kalimantan Tengah adalah curah hujan, suhu, kelerengan, jenis tanah, rawan erosi, rawan banjir, jarak dari pusat perkotaan, kedekatan dengan sungai, jarak dari lokasi pertambangan dan kedekatan dengan lokasi industri pengolahan.

2. Variabel bahaya banjir dan kedekatan dengan lokasi industri kelapa sawit merupakan variabel dengan bobot terbesar sehingga arah pengembangan lahan perkebunan kelapa sawit sangat memperhatikan dan bergantung pada kedua variabel tersebut.

3. Hasil model simulasi skenario perkembangan lahan perkebunan kelapa sawit berdasarkan trend menunjukan penambahan luas lahan perkebunan kelapa sawit sebesar 97,70 \% atau 234306 sel dengan lahan yang terkonversi adalah hutan produksi sebesar 150675 sel (941718,75 Ha), perkebunan lainnya sebesar 30140 sel (188375 Ha), pertanian lahan basah 10938 sel $(68362,5 \mathrm{Ha})$, pertanian lahan kering sebesar 10074 sel $(62962,5 \mathrm{Ha})$, rawa sebesar 1520 sel (9500 Ha), semak/belukar 29244 sel (182775 Ha) dan tanah terbuka sebesar 1711 sel $(10693,75 \mathrm{Ha})$.

4. Hasil model simulasi skenario perkembangan lahan perkebunan kelapa sawit berdasarkan target pedoman teknis menunjukan penambahan luas lahan perkebunan kelapa sawit sebesar sebesar 78,16\% atau 187445 sel dengan lahan yang terkonversi adalah hutan produksi sebesar 119356 sel (745975 Ha), perkebunan lainnya sebesar 25972 sel (162325Ha), pertanian lahan basah 9998 sel $(62487,5 \mathrm{Ha})$, pertanian lahan kering sebesar 7591 sel $(47443,75 \mathrm{Ha})$, rawa sebesar 1288 sel $(8050 \mathrm{Ha})$, semak/belukar 21652 sel (135325 Ha) dan tanah terbuka sebesar 1584 sel (9900 Ha).

5. Hasil model simulasi skenario perkembangan lahan perkebunan kelapa sawit berdasarkan target RTRW menunjukan penambahan luas lahan perkebunan kelapa sawit sebesar sebesar 97,70 \% atau 234306 sel dengan lahan yang terkonversi adalah hutan produksi sebesar 121626 sel (760162,5 Ha), perkebunan lainnya sebesar 40026 sel (250162,5 Ha), pertanian lahan basah 12208 sel $(76300 \mathrm{Ha})$, pertanian lahan kering sebesar 16645 sel (104031,3 Ha), rawa sebesar 1612 sel (10075 Ha), semak/belukar 39877 sel (249231,3 Ha) dan tanah terbuka sebesar 2308 sel (14425 Ha).

6. Model spasial berdasarkan target RTRW lebih sesuai diterapkan di Provinsi Kalimantan Tengah karena pengembangan lahan perkebunan kelapa sawit pada hutan produksi hanya dilakukan pada jenis lahan hutan produksi yang dapat dikonversi, sedangkan model simulasi berdasarkan skenario trend dan pedoman teknis tidak di akomodasi oleh pembagian jenis hutan produksi sehingga pengembangan lahan perkebunan kelapa sawit 
mengkonversi lahan hutan produksi tetap dan hutan produksi terbatas.

\section{DAFTAR PUSTAKA}

[1] Bratakusumah, D. Supriady, and Riyadi, Perencanaan Pembangunan Daerah. Jakarta: Gramedia Pustaka Utama, 2003.

[2] BPS Provinsi Kalimantan Tengah, "Data luas lahan perkebunan kelapa sawit tahun 2012-2017," Kalimantan Tengah, 2017.

[3] Global Green Growth Institute, "Kalimantan Tengah Menuju Pertumbuhan Ekonomi Hijau,” 2015.
[4] Dinas Perkebunan Provinsi Kalimantan Tengah, "Data luas lahan perkebunan kelapa sawit tahun 2007," Kalimantan Tengah, 2007.

[5] S. Thomas L, Decision Making For Leaders,. The Analytical Hierarchy Process for Decisions in a Company World. Pittsburgh: RWS Publication, 1985.

[6] N. Pratomoatmojo, "LanduseSim sebagai aplikasi pemodelan dan simulasi spasial," in Seminar Nasional Cities: Eco City Utopis or realistis?, 2014

[7] N. A. Pratomoatmojo, "Land Use Change Modelling Under Tidal Flood Scenario by Means of Markov Cellular Automata in Pekalongan Municipal," Universitas Gadjah Mada, 2012. 